NBER WORKING PAPER SERIES

\title{
A MODEL OF FOREIGN EXCHANGE RATE INDETERMINATION
}

Charles Engel

Working Paper 5766

\author{
NATIONAL BUREAU OF ECONOMIC RESEARCH \\ 1050 Massachusetts Avenue \\ Cambridge, MA 02138 \\ September 1996
}

I appreciate helpful comments from a number of colleagues in the field. Some of the work on this paper was completed while I was a visiting scholar at the Federal Reserve Bank of Kansas City. The views expressed in this paper are my own and are not necessarily shared by the Federal Reserve Bank of Kansas City or the National Bureau of Economic Research. I acknowledge assistance from the National Science Foundation, NSF grant \#SBR-932078. This paper is part of NBER's research program in International Finance and Macroeconomics, and NBER's project on International Capital Flows. We are grateful to the Center for International Political Economy for the support of this project. Any opinions expressed are those of the author and not those of the National Bureau of Economic Research.

(C) 1996 by Charles Engel. All rights reserved. Short sections of text, not to exceed two paragraphs, may be quoted without explicit permission provided that full credit, including $\mathbb{C}$ notice, is given to the source. 
NBER Working Paper 5766

September 1996

\title{
A MODEL OF FOREIGN EXCHANGE \\ RATE INDETERMINATION
}

\begin{abstract}
Economic agents undertake actions to protect themselves from the short-run impact of foreign exchange rate fluctuations: Nominal goods prices are set in consumers' currencies, and firms hedge foreign exchange risk. A model is presented here which shows that these features of the economy can lead to indeterminacy in the nominal exchange rate in the short run. There can be noise in the exchange rate, unrelated to any fundamentals, essentially because the short-run fluctuations do not influence any rational agent's behavior. Empirical implications of this sort of noise are explored.
\end{abstract}

Charles Engel

Department of Economics

University of Washington

Seattle, WA 98195

and NBER

CMENGEL@U.WASHINGTON.EDU 
Since the collapse of the Bretton Woods system in the early 1970s, nominal exchange rates among industrialized countries have been extremely volatile. The short-run movements in exchange rates have been much more extreme than early proponents of floating rates (such as Friedman (1953) and Johnson (1972)) envisaged.

Two notable puzzles that arise in relation to this volatility are:

(1) What accounts for the volatility? Some of the theoretical models of the 1970 s were specifically designed to explain how the nominal exchange rate could be much more volatile than the underlying economic fundamentals (notably Dornbusch (1976)). But these models have fared very badly empirically. Meese and Rogoff (1983a, 1983b), and subsequently many others, have documented the failure of these models in explaining short-run movements of exchange rates. While the models are more successful at longer horizons (Mark (1995), Chinn and Meese (1995)), the movement of exchange rates at short horizons seems independent of the movement in what are hypothesized to be the underlying economic fundamentals (Flood and Rose (1995)).

(2) Despite the huge variability in nominal exchange rates, international trade does not appear to have been greatly adversely affected (see, for example, Kroner and Lastrapes (1993)). On the contrary, there has been a steady opening of markets and expansion in the volume of trade.

The story of this paper is simple: In the short run, nominal exchange rate changes have essentially no real effects. But, since a change in the exchange rate does not affect any agent's behavior, the level of the exchange rate is indeterminate. Purely extrinsic noise causes the exchange rate to fluctuate around the equilibrium value determined by the fundamentals.

There are two essential elements to the model presented here. First, recent work has noted that nominal exchange rate fluctuations have little effect on the prices 
consumers pay (Knetter (1989, 1993), Engel (1993), Engel and Rogers (1996)). There appears to be forces of both pricing to market and nominal price stickiness at work in international markets. Producers charge different prices for similar goods in different markets. A German producer might charge one price for its product at home, and another price for sale in the U.S. The reasons for this type of price discrimination have been explored extensively in recent literature (see, for example, Krugman (1987), Dombusch (1987), Marston (1990)). Prices may not respond to exchange rate changes either for reasons explored in the "pass-through" literature, or because there are menu-costs to changing prices (such as in Mankiw (1985)).

While nominal price stickiness has been a feature of a long line of models of exchange rates, generally the price stickiness in these models is of a different sort than has been observed in the data. Dornbusch (1976), for example, assumes that exporters set prices in their own currencies. If the dollar depreciates relative to the mark, imports from Germany become more expensive for Americans in the Dornbusch formulation. But, the evidence suggests that, because firms price to market, they set the price in the currency of the country that buys the good. German firms set the price of their exports to the U.S. in dollar terms. A change in the exchange rate has no effect on that price in the short run. ${ }^{1}$

There is an effect on the profits of a German firm, however, if the dollar depreciates and the German firm's export price is fixed in dollars. The revenue per item sold will decline in mark terms. The German firm's profits are adversely affected. But, that leads to the second essential element of the model in this paper. Firms can hedge against exchange rate fluctuations. A sufficiently insured firm can fully hedge against losses from exchange rate fluctuations that are purely noise.

1 Some of the evidence in the pricing-to-market literature suggests that U.S firms are different than other firms in their pricing behavior. But, Rangan and Lawrence (1993) argue that this is an incorrect inference based on faulty data. 
Indeed, in the simple model presented here, all fluctuations in the exchange rate are extrinsic. The exchange rate moves at the whim of foreign exchange traders. But that noise affects nobody. Consumers are unaffected because the prices they face are fixed and unresponsive to exchange rate changes. The exchange rate risk that firms face is fully diversifiable. The firms simply make contracts that specify that the winners from exchange rate changes pay off the losers. Since the exchange rate fluctuations have no other real effects, the firms desire these contracts -- their expected return is unchanged by the contracts, but the risk from exchange rate fluctuations is eliminated.

The model in this paper is different than other recent models of exchange rate indeterminacy (e.g., King, Wallace and Weber (1992), Manuelli and Peck (1990)). Here, the indeterminacy arises from two specific observable features of the international economy -- pricing-to-market and hedging of exchange rate risk. The idea of this paper does build naturally on the notion that pricing to market increases exchange rate volatility in equilibrium (Krugman (1989), Betts and Devereux (1996)). In the model of this paper, there is "excess" volatility, in the sense that purely extrinsic noise affects the exchange rate.

Section 1 presents a simple static general equilibrium model of two countries with a large number of firms selling products at home and abroad. The model is one with flexible prices and a determinate exchange rate. Its purpose is to determine the expected prices and exchange rates that firms and consumers face. In section 2 , we require that prices be set in advance of the determination of the exchange rate. Prices will be set at the equilibrium level from section 1 . Firms will also make contracts to hedge the risk of the exchange rate ending up at some level other than the expected rate from the model of section 1 . The exchange rate will be seen to be indeterminate.

Section 3 discusses some of the empirical implications of this model. One is that there will be little relation between exchange rates and fundamentals in the short run, 
but that they will be closely related in the long run. Other possible avenues for empirical work for future versions of this paper are discussed. The section also considers implications of this model for other issues, such as the responsiveness of trade to exchange rate changes, and the choice of nominal exchange rate regime.

There is one major determinant of exchange rates that the model ignores -- the role of speculation in stabilizing the exchange rate. In the model, the exchange rate is influenced by extrinsic noise in the short-run, which implies that there is an expected profit opportunity for speculators who bet that the exchange rate will return to its fundamental value. This speculation ought to help nail down the exchange rate. On the other hand, hundreds of studies of forward foreign exchange rate market efficiency have documented the empirical regularity that the forward rate is a biased predictor of future spot rates, and have made essentially no progress in explaining this bias with models of rational risk-averse economic agents (see Hodrick (1987) and Engel (1996) for comprehensive surveys.) It is difficult to reject the conclusion that foreign exchange market speculators do allow expected profit opportunities to go unexploited. But, this paper does not attempt to tackle that difficult subject: it sidesteps it completely. It seems likely, however, that the issues raised here concerning how economic agents protect themselves from the effects of foreign exchange rate fluctuations could play a role in future research into understanding the efficiency or inefficiency of international capital markets.

\section{The Equilibrium Model}

The model is of two countries, call them the U.S. and Germany, that are identical in the sense that consumers have the same utility functions, producers have the same 
production functions, and the economies are of the same size. This is a model with no uncertainty.

\section{Consumers}

Consumers in the U.S. maximize

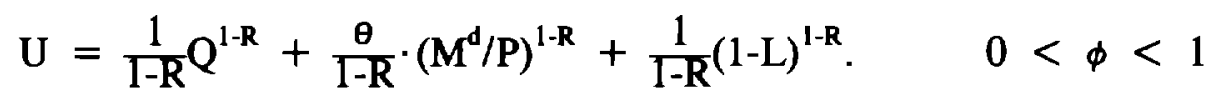

where

$$
Q=\left(\int_{0}^{1} q_{i}^{1-\phi} d i\right){ }^{1 /(1-\phi)} .
$$

In this function, $q_{i}$ is consumption of good $i$. The range from 0 to $1 / 2$ are produced in the U.S., and the goods indexed from $1 / 2$ to 1 are produced in Germany. $\mathbf{M}^{d}$ is the nominal quantity of money demanded by Americans. L is supply of labor.

$P$ is defined by

$$
P=\left(\int_{0}^{1} p_{i}^{(\phi-1) / \phi} d i\right)^{\phi /(\phi-1)} .
$$

Some points about the utility function can be briefly noted. All goods enter utility symmetrically. The restriction that $\phi$ lie between zero and unity is necessary for an equilibrium with monopolistic producers of each good. Real balances appear in the utility function as a simple way of capturing the transactions motive for holding money. $\mathrm{R}$ can be interpreted as the measure of relative risk aversion for consumers. ${ }^{2}$

The budget constraint faced by an American is

$$
\int_{0}^{1} \mathbf{p}_{i} q_{i} d i+M^{d}=w L+M+\pi .
$$

The price of good $i$ is $p_{i}$. All of these prices are expressed in terms of dollars. The wage rate paid in competitive labor markets is $w$. All individuals receive a transfer of money, M. Finally, all individuals are endowed with equal ownership in each of the American firms. $\pi$ is the amount of profits paid to the representative American.

\footnotetext{
2 See the discussion on risk aversion and risk neutrality with multiple goods in Engel (1992).
} 
The first-order conditions for goods, money and labor demands imply:

$$
\begin{aligned}
& \mathrm{q}_{\mathrm{i}}=\left(\mathrm{p}_{\mathrm{i}} / \mathrm{P}\right)^{-1 / \phi} \mathrm{Q}, \\
& \mathbf{M}^{\mathrm{d}}=\mathrm{PQ} \theta^{1 / \mathrm{R}}, \\
& \mathrm{L}=1-\mathrm{Q}(\mathrm{P} / \mathrm{w})^{1 / \mathrm{R}} .
\end{aligned}
$$

Symmetrically, the optimization problem faced by Germans is to maximize

$$
\mathrm{U}^{*}=\frac{1}{1-\mathrm{R}} \mathrm{Q}^{* 1-\mathrm{R}}+\frac{\theta}{1-\mathrm{R}} \cdot\left(\mathrm{M}^{* \mathrm{~d}} / \mathrm{P}^{*}\right)^{1-\mathrm{R}}+\frac{1}{\left.1-\mathrm{R}^{\left(1-\mathrm{L}^{*}\right.}\right)^{1-\mathrm{R}} . \quad 0<\phi<1}
$$

subject to

$$
\int_{0}^{1} p_{i}^{*} q_{i}^{*} d i+M^{* d}=w^{*} L^{*}+M^{*}+\pi^{*} .
$$

Two things to note: Germans hold marks. There is no currency substitution. Also, the budget constraint is expressed in terms of marks.

Goods, money and labor demands for Germans are given by:

$$
\begin{aligned}
& q_{i}^{*}=\left(p_{i}^{*} / P^{*}\right)^{-1 / \phi} Q^{*}, \\
& M^{* d}=P^{*} Q^{*} \theta^{1 / R}, \\
& L^{*}=1-Q^{*}\left(P^{*} / w^{*}\right)^{1 / R} .
\end{aligned}
$$

\section{Firms}

For $\mathrm{i}<1 / 2$, goods are produced in the U.S.; and for $\mathrm{i}>1 / 2$, goods are produced by German firms. Each good is produced by a monopolist. The production function is simply:

$$
\mathrm{y}_{\mathrm{i}}=\frac{1}{\alpha} \mathrm{L}_{\mathrm{i}} \text {. }
$$

Firms set prices for Americans in dollar terms and for Germans in mark terms. In this section, this has no particular importance, but it will come into play in the next section in which we assume nominal price stickiness.

We assume the population in each country is unity, so that demand for firm i's product from Americans is $\mathrm{q}_{\mathrm{i}}$ and from Germans is $\mathrm{q}_{\mathrm{i}}^{*}$. So,

$$
\mathrm{y}_{\mathrm{i}}=\mathrm{q}_{\mathrm{i}}+\mathrm{q}_{\mathrm{i}}^{*} \text {. }
$$

The American firms maximize

$$
\pi_{\mathrm{i}}=\mathrm{p}_{\mathrm{i}} \mathrm{q}_{\mathrm{i}}+\mathrm{sp}_{\mathrm{i}}^{*} q_{\mathrm{i}}^{*}-w \alpha\left(\mathrm{q}_{\mathrm{i}}+\mathrm{q}_{\mathrm{i}}^{*}\right)
$$


Here, $s$ is the dollar price of marks. We have expressed the firm's objective in nominal terms, but as there is no uncertainty in this model, this makes no difference.

The firm can charge different prices to the two markets. There is no possibility for arbitrage by consumers. The optimal prices for the firm are:

$$
\begin{aligned}
& p_{i}=\frac{\alpha w}{1-\phi}, \\
& p_{i}^{*}=\frac{\alpha w}{s(1-\phi)} .
\end{aligned}
$$

These are the standard mark-up pricing rule for a monopolist facing demand curves with constant elasticities.

For $\mathrm{i}>1 / 2$, the German firm sets prices for its own market and for the American market. Its pricing rule is:

$$
\begin{aligned}
& \mathrm{p}_{\mathrm{i}}=\frac{s \alpha \mathrm{w}^{*}}{1-\phi}, \\
& \mathrm{p}_{\mathrm{i}}^{*}=\frac{\alpha \mathrm{w}^{*}}{1-\phi} .
\end{aligned}
$$

We note that profits are distributed to the consumer-owners of the firms:

$$
\begin{aligned}
& \Pi=\int_{0}^{1 / 2} \pi_{i} \mathrm{di}, \\
& \Pi^{*}=\int_{1 / 2}^{1} \pi_{\mathrm{i}}^{*} \mathrm{di} .
\end{aligned}
$$

\section{Equilibrium}

Equilibrium requires in each country that money demand equal money supply and labor demand equal labor supply. Each firm operates along the demand curve that it faces, so each goods market will be in equilibrium for optimizing firms. The aggregate budget constraint in each country must also be satisfied.

From the money market equilibrium conditions, we have

$$
\mathbf{M}^{\mathrm{d}}=\mathbf{M} ; \mathbf{M}^{* \mathrm{~d}}=\mathbf{M}^{*} \text {. }
$$

Given that the money market is in equilibrium, the aggregate American budget constraint can be written as: 
$\int_{0}^{1} p_{i} q_{i} d i=w L+\pi$.

From the definition of profits

$\Pi=\int_{0}^{1 / 2} \pi_{i} d i=\int_{0}^{1 / 2}\left(p_{i} q_{i}+s p_{i}^{*} q_{i}^{*}\right) d i-w L$.

So, the budget constraint can be rewritten as

$s_{1 / 2}^{1} p_{i} q_{i} d i=\int_{0}^{1 / 2} s_{i}^{*} q_{i}^{*} d i$.

Seen this way, the budget constraint in the U.S. is the constraint that the value of the its imports, $s_{1 / 2}^{1} \mathrm{p}_{i} \mathrm{q}_{\mathrm{j}} \mathrm{di}$, equals the value of its exports, $\int_{0}^{1 / 2} s \mathrm{p}_{i}^{*} \mathrm{q}_{i}^{*} \mathrm{di}$.

Solving for the equilibrium yields:

$$
\begin{aligned}
& \mathrm{L}=\mathrm{L}^{*}=\frac{\alpha}{\alpha+(\alpha /(1-\phi))^{1 / \mathrm{R}}} ; \\
& \mathrm{q}_{\mathrm{i}}=\mathrm{q}_{\mathrm{i}}^{*}=\frac{1}{\alpha+(\alpha /(1-\phi))^{1 / \mathrm{R}}} ; \\
& \mathrm{p}_{\mathrm{i}}=\mathrm{M}^{-1 / \mathrm{R}}\left(\alpha+(\alpha /(1-\phi))^{1 / \mathrm{R}}\right) ; \mathrm{p}_{\mathrm{i}}^{*}=\mathrm{M}^{*} \theta^{-1 / \mathrm{R}}\left(\alpha+(\alpha /(1-\phi))^{1 / \mathrm{R}}\right) ; \\
& \mathrm{w}=\frac{1-\phi}{\alpha} \mathrm{M}^{-1 / \mathrm{R}}\left(\alpha+(\alpha /(1-\phi))^{1 / \mathrm{R}}\right) ; \mathrm{w}^{*}=\frac{1-\phi}{\alpha} \mathrm{M}^{*} \theta^{-1 / \mathrm{R}}\left(\alpha+(\alpha /(1-\phi))^{1 / \mathrm{R}}\right) ;
\end{aligned}
$$

and

$s=\frac{M}{M^{*}}$.

2. Price stickiness and exchange rate indeterminacy

Now we will consider an alternative view of markets, in which firms must set nominal prices first, and then financial markets determine the exchange rate.

Recent empirical work suggests that prices are sticky in terms of the consumer's currency. We will assume stickiness of this sort. Implicitly, we assume that there are some menu costs to changing prices, although the menu costs are not modeled explicitly.

In the model of this section, firms must choose prices before the wage rate and the exchange rate are realized. There is no intrinsic uncertainty in the model. The 
exogenous variables (such as the money supplies) are not subject to random shocks. But there can be extrinsic uncertainty. The exchange rate's value is a random variable that does not depend on the exogenous fundamentals. We will derive the properties of the distribution of that random variable.

Consumers make their choices with full certainty about the economic environment. They know all goods prices, the wage rate, the exchange rate, firms' profits, etc. So, their optimization problem is exactly the same as the one described in section 1 . Their demand curves are the same as in that section.

For the firms, we assume that each American firm can buy units of a contract of the following form: if the actual exchange rate, $s^{\prime}$, is greater than $\widetilde{s}$, the equilibrium exchange rate from section 1 , the firm gives $\left(\frac{s^{\prime}}{s}-1\right)$ to the insurer for each dollar of insurance the firm has purchased. Likewise, if $s^{\prime}$ is less than $\widetilde{s}$, the firm receives $-\left(\frac{s^{\prime}}{\widetilde{s}}\right.$

- 1) from the insurer for each dollar of insurance.

We will also assume that if $\mathbf{s}^{\prime}$ is greater than $\boldsymbol{s}$, that each foreign firm receives $\left(1-\frac{5}{s^{\prime}}\right)$ from the insurer for each mark of insurance they buy, and they pay $-\left(1-\frac{\widetilde{S}}{s^{\prime}}\right)$ when $\mathbf{s}^{\prime}$ is less than $\mathbf{s}$.

We note that the profits of the domestic firm are given by:

$$
\pi_{\mathrm{i}}=\mathrm{p}_{\mathrm{i}} \mathrm{q}_{\mathrm{i}}+\mathrm{s}^{\prime} \mathrm{p}_{\mathrm{i}}^{*} \mathrm{q}_{\mathrm{i}}^{*}-\mathrm{w \alpha}\left(\mathrm{q}_{\mathrm{i}}+\mathrm{q}_{\mathrm{i}}^{*}\right)-\left(\frac{\mathrm{s}^{\prime}}{\mathrm{s}}-1\right) \mathrm{x}_{\mathrm{i}}-\mathrm{C}\left(\mathrm{x}_{\mathrm{i}}\right) \text {. }
$$

where $x_{i}$ is dollars of insurance that the firm purchases and $C$ is the cost of the insurance contract. There is a similar function for the expected profits of the foreign firm:

$$
\pi_{i}^{*}=\frac{p_{i} q_{i}}{\mathbf{s}^{\prime}}+p_{i}^{*} q_{i}^{*}-w^{*} \alpha\left(q_{i}+q_{i}^{*}\right)+\left(1-\frac{\widetilde{s}}{s^{\prime}}\right) x_{i}^{*}-C^{*}\left(x_{i}^{*}\right) .
$$

We now claim an equilibrium is given by:

$$
\mathrm{q}_{\mathrm{i}}=\mathfrak{q}_{\mathrm{i}}, \mathrm{q}_{\mathrm{i}}^{*}=\mathfrak{q}_{\mathrm{i}}^{*}
$$




$$
\begin{aligned}
& \mathrm{p}_{\mathrm{i}}=\tilde{\mathrm{p}}_{\mathrm{i}}, \mathrm{p}_{\mathrm{i}}^{*}=\tilde{\mathrm{p}}_{\mathrm{i}}^{*} ; \\
& w=w, w^{*}=w^{*} ; \\
& x_{i}=s p_{i}^{*} q_{i}^{*} ; \\
& \mathbf{x}_{\mathrm{i}}^{*}=\frac{\tilde{\mathbf{p}}_{\mathrm{i}} \tilde{\mathrm{q}}_{\mathrm{i}}}{\boldsymbol{s}} ; \\
& \mathrm{C}\left(\mathrm{p}_{\mathrm{i}}^{*} q_{\mathrm{i}}^{*}\right)=0, \mathrm{C}^{*}\left(\frac{\mathrm{p}_{\mathrm{i}} \mathrm{q}_{\mathrm{i}}}{\mathrm{s}}\right)=0 \text {; }
\end{aligned}
$$

and $s^{\prime}$ is a random draw from a distribution in which $E\left(\ln \left(s^{\prime}\right)\right)=\ln (s)$.

In the notation above, a " " refers to the equilibrium value of the variable from Section 1.

To show this is an equilibrium, we will see that at these values consumers (domestic and foreign) and firms (domestic and foreign) have no incentive to change their behavior.

First note that in this equilibrium

$$
\pi_{i}=\tilde{p}_{i} \widetilde{q}_{i}+\widetilde{s} \tilde{p}_{i}^{*} q_{i}^{*}-\varpi \alpha\left(\widetilde{q}_{i}+q_{i}^{*}\right) \text {. }
$$

Profits for the domestic firm are exactly the same as in section 1. Likewise, for the foreign firm in equilibrium,

$$
\pi_{i}^{*}=\frac{\mathbf{p}_{i} \widetilde{q}_{i}}{\mathbf{s}}+\tilde{p}_{i}^{*} q_{i}^{*}-w^{*} \alpha\left(q_{i}+q_{i}^{*}\right),
$$

which is exactly the same level of profits the firm received in section 1 in equilibrium.

So, consider the problem facing a domestic consumer. The profits it receives, $\Pi$, are the same as in section 1; it receives the same money transfer, $\mathbf{M}$, from the government; and, the wages and prices it faces are the same as in section 1. Hence, it will choose the same quantities of each good, and the same quantity of money; and, it will supply the same quantity of labor. A similar argument holds for foreign consumers. Turning to the firms, first consider the US. firm, which must choose prices and $x_{i}$ 
before the exchange rate is known. We assume that the managers of the firm are concerned not only with the expected profits, but also are concerned with the uncertainty about profits. Americans cannot buy shares in German firms, and vice-versa. So, Americans cannot diversify exchange risk through their portfolio holdings. Hence, the owners of the firms direct the managers to diversify the risk so as to maximize the owners' expected utility.

Assume for the moment that $\mathrm{s}^{\prime}$ is distributed such that $\mathrm{E}\left(\mathrm{s}^{\prime}\right)=\widetilde{s}$. Then, the expected profits for the U.S. firm in the proposed equilibrium are

$$
E\left(\pi_{i}\right)=p_{i} q_{i}+\widetilde{s} p_{i}^{*} q_{i}^{*}-\mathfrak{w} \alpha\left(q_{i}+q_{i}^{*}\right) .
$$

Note that the expected profits are not a function of the amount of insurance purchased. The firm can eliminate all risk and not affect its expected profits if it purchases $x_{i}=$ $\widetilde{s} \mathrm{p}_{\mathrm{i}}^{*} \mathrm{q}_{\mathrm{i}}^{*}$. In this case, the firm's profits are independent of the actual exchange rate, $s^{\prime}$. The firm's profits will be known with certainty, so the firm chooses its price to maximize its profits, given by:

$$
\pi_{\mathrm{i}}=\mathrm{p}_{\mathrm{i}} \mathrm{q}_{\mathrm{i}}+\widetilde{s} \mathrm{p}_{\mathrm{i}}^{*} \mathrm{q}_{\mathrm{i}}^{*}-w \alpha\left(\mathrm{q}_{\mathrm{i}}+\mathrm{q}_{\mathrm{i}}^{*}\right) .
$$

Since this is exactly the problem the firm faces in section 1 , it chooses $q_{i}=q_{i} ; q_{i}^{*}=$ $\tilde{q}_{i}^{*} ; p_{i}=\tilde{p}_{i} ;$ and, $p_{i}^{*}=\tilde{p}_{i}^{*}$.

A similar argument would apply to the German firm.

Since consumers' choices are the same as in section 1, and producers choices are the same, clearly the same values of $q_{i}, q_{i}^{*}, p_{i}, p_{i}^{*}$, w and $w^{*}$ will be equilibrium values. We still need to show that $C\left(\widetilde{S} \tilde{p}_{i}^{*} q_{i}^{*}\right)=0$ and, $C^{*}\left(\frac{p_{i} q_{i}}{\widetilde{s}}\right)=0$. To see this, note that the total payout by American firms is

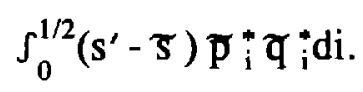

The total receipts by German firms, expressed in dollar terms are 


$$
\int_{1 / 2}^{1}\left(s^{\prime}-\mathbf{s}\right) \frac{\tilde{p}_{i} \widetilde{q}_{i}}{s} \text { di. }
$$

The total payout by American firms equals the total receipts by German firms, since

$$
\int_{0}^{1 / 2} \mathrm{~s} \mathbf{p}_{i}^{*} q_{i}^{*} \mathrm{di}=S_{1 / 2}^{1} \tilde{p}_{i} q_{i} d i
$$

by the equilibrium condition from section 1 .

The net payout is zero, irrespective of the realization of the exchange rate, $\mathbf{s}^{\prime}$. If the administrative costs of providing insurance are zero, and the insurance market is competitive, the price of the insurance will equal its cost -- zero -- in equilibrium.

This demonstrates that an equilibrium exists in which consumers' purchases are the same as the equilibrium quantities in section 1, prices and wages are the same as in section 1, profits for all firms are the same as in section 1, and employment is the same as in section 1. All of this is independent of the actual level of the exchange rate, $s^{\prime}$. So, there is nothing that ties down the exchange rate -- it is indeterminate.

Something has been swept under the rug in the derivation of the equilibrium above, but now it must be brought out into the open.

Suppose $E\left(s^{\prime}\right)=\widetilde{s}$, as we postulated when solving the U.S. firm's problem. Then, clearly, the American firm's expected profits under uncertainty with no insurance contract are the same as their actual profits in section 1. This firm would fully insure against exchange rate fluctuations if the insurance were free.

But, the foreign firm's expected profits in this case are higher than its certain profits when the exchange rate equals $\mathfrak{s}$. To see this, note that when the exchange rate equals $\boldsymbol{s}$, its revenues from sales to the domestic country, expressed in foreign currency terms are $\frac{\vec{p}_{i} \bar{q}_{i}}{\tau}$. But,

$$
E\left(\frac{\tilde{p}_{i} \tilde{q}_{i}}{\mathbf{s}^{\prime}}\right)>\frac{\tilde{p}_{i} q_{i}}{\widetilde{s}}, \text { if } E\left(s^{\prime}\right)=s,
$$


because $\mathrm{E}\left(1 / \mathrm{s}^{\prime}\right)>1 / \mathrm{E}\left(\mathrm{s}^{\prime}\right)$ by Jensen's inequality.

Why might the firms diversify all of their exchange rate risk, as postulated in the equilibrium? First, note that the firms would want to diversify a pretty large fraction of this risk even though the expected return from the risky situation is greater than in the riskless situation.

Suppose, for example that $s^{\prime}$ were distributed such that $E\left(\ln \left(s^{\prime}\right)\right)=\ln (\widetilde{s})$-- which is how the equilibrium is described above. (If the equilibrium distribution of exchange rates has this property, the hedging problem faced by American and German firms is symmetric.) Then the Appendix shows that assuming $\ln \left(\mathrm{s}^{\prime}\right)$ is normally distributed, a risk averse firni would want to insure a fraction $\frac{2 R-(1 / \gamma)}{2 R}$ of the profits, where $R$ is the coefficient of relative risk aversion and $\gamma$ is the fraction of expected revenues derived from foreign sales.

Recent empirical studies of foreign exchange markets suggest that models using expected utility analysis have a hard time explaining the size of the foreign exchange risk premium unless consumers are assumed to be very risk averse (see Engel (1996)). So, to calibrate the share of profits that are hedged in the expected utility framework, we should choose a large value of $R$. For example, Mark (1985) estimates a value greater than 50. If $\gamma=1 / 2$, then the firms would hedge 98 per cent of the risk. If $R$ equals ten, 90 per cent of the risk is hedged.

If there is a small cost for consumer-owners to monitor the exchange rate, the owners will instruct firm managers to hedge 100 per cent of the exchange rate risk.

If it were not for the effect of exchange rates on their firms' profits, consumers would have no reason to know the exchange rate. They face prices and wages denominated in their own currency. If the firm did not hedge all of the exchange rate risk, the consumers would have to monitor exchange rates in order to know what dividends they are supposed to receive from the firm. If they did not know the exchange rate, the managers 
might lie to the owners about the effect of the exchange rate on the profits -- for instance, claiming a loss from exchange rate fluctuations when in fact there was a gain (so the managers could pocket the difference.)

If the managers were instructed to hedge all exchange rate risk, the profits of the firm would be independent of the exchange rate. Even though $100 \%$ hedging is not optimal if monitoring costs are zero, we have shown that it is nearly so. When there are some small monitoring costs, it will be optimal for the owners to instruct the firm managers to hedge all exchange rate risk.

Note that it is important that the exchange rate is centered on the equilibrium exchange rate. That is, $\mathrm{E}\left(\ln \left(\mathrm{s}^{\prime}\right)\right)=\ln (\widetilde{s})$. If the mean of the exchange rate were much different than its fundamental value from section 1, then either the American firms or the German firms would find they would want to hedge far less than 100 per cent of the exchange rate risk, because there would be a trade-off between risk and return. For example, if $E\left(\ln \left(s^{\prime}\right)\right)$ was much greater than $\ln (\widetilde{s})$, domestic firms' expected profits would increase significantly as the fraction of profits hedged was smaller. The implication here is that even though the exchange rate is indeterminate in the model, the indeterminacy is of a particular form. The noise in the exchange rate is not systematic, so that $E\left(\ln \left(s^{\prime}\right)\right)=\ln (s)$.

The argument for indeterminacy rests on firms hedging 100 per cent of the risk. If they did not, then $s^{\prime}$ affects firms' profits. This would in turn have an income effect for consumers which would affect their demands. But, then the equilibrium would depend on $s^{\prime}$. But, if owners want to avoid the cost of monitoring the exchange rate, so they have the managers hedge 100 per cent of the exchange rate risk, the exchange rate will be indeterminate. 


\section{Empirical Implications and Directions for Future Research}

The model here is static. As was noted in the introduction, a fully dynamic model would need to capture the behavior of foreign exchange speculators. We do not attempt that here. If we abstract from international capital markets, allowing no borrowing or lending, ${ }^{3}$ then the dynamic model would be the static model repeated period by period.

The model does have a useful and interesting empirical implication. The basic result here is that in any period, the log of the exchange rate is equal to its fundamental value plus a mean-zero extrinsic error term:

$$
\ln \left(s_{\mathfrak{l}}\right)=f_{t}+\varepsilon_{t} .
$$

Now, suppose that the fundamentals have a unit root. The previous equation implies that the exchange rate and the fundamentals are cointegrated. In the long run they move together.

Nonetheless, the short run correlation in their changes could be quite low. Note that

$$
\ln \left(s_{t+1}\right)-\ln \left(s_{t}\right)=\hat{f}_{t+1}-f_{t}+\varepsilon_{t+1}-\varepsilon_{t} .
$$

If $f_{\mathrm{l}}$ follows a random walk,

$$
f_{t+1}=f_{t}+u_{t+1}
$$

then the correlation between $\ln \left(s_{t+1}\right)-\ln \left(s_{t}\right)$ and $f_{t+1}-f_{t}$ is equal to

$$
\frac{\sigma_{u}}{\left(\sigma_{u}^{2}+2 \sigma_{\varepsilon}^{2}\right)^{1 / 2}}
$$

where $\sigma_{u}^{2}$ is the variance of $u_{t}$ and $\sigma_{\varepsilon}^{2}$ is the variance of $\varepsilon_{\mathrm{t}}$. This correlation could be fairly small if the variance of the extrinsic noise, $\sigma_{\varepsilon}^{2}$, were large.

This observation is consistent with the recent literature on empirical exchange

$$
\text { Roubini (1992). }
$$


1ate models. While it has been shown that in the short run the relation between the exchange rate and the fundamentals is tenuous (Meese and Rogoff (1983a, 1983b) and Frankel and Meese (1987)), recent work shows that in the long run exchange rates and fundamentals are related (Chinn and Meese (1995), Mark (1995), and MacDonald and Taylor (1994)). This model also implies that there is excess volatility of the exchange rate, in the sense of Huang (1981), or bubbles as defined by Meese (1986).

Another implication of the model is that the volume of trade does not change much in response to changes in the exchange rate. Of course, this is exactly the empirical observation that motivated the entire literature on exchange-rate pass-through.

Flood and Rose (1995) have noted that the volatility of the exchange rate is unrelated to the volatility of fundamentals. Specifically, when nominal exchange rates are fixed or targeted within narrow bands, the fundamentals are no less variable than when exchange rates are floating. That finding is exactly consistent with the model presented here. A further implication of the model in this paper is that the choice of nominal exchange rate regime does not much matter for short-run considerations. Exchange rate volatility does not concern any agents because it does not affect consumers' prices, and firms hedge away the exchange rate risk.

The model presented in this paper raises several interesting issues for further research:

We take the menu-cost pricing as exogenously given. However, it seems plausible that nominal prices of imported goods would respond less to nominal exchange rate changes if the exchange rate changes were not based on changes in fundamentals. As we have noted, these exchange rate fluctuations tend to be transitory. In dynamic models of menu-cost pricing, firms tend are less likely to change prices in response to transitory shocks. This presents the possibility of an interesting source of feedback between menucost pricing and exchange-rate instability. On the one hand, a principle source of the 
short-run indeterminacy of the exchange rate in our model is the menu-cost pricing. But, firms may be more likely to choose menu-cost pricing in the face of short-run nonfundamental fluctuations in exchange rates.

We have ignored the effects of exchange rate fluctuations on the values of foreignheld assets in our model. This may not be a bad approximation, given the extreme homebias in asset holdings that has been noted. Perhaps the model presented here could even help explain that home bias. Empirical models have indicated that the variance of investors' portfolios could be substantially reduced with more international diversification. ${ }^{4}$ But, those estimates may overstate the gains from diversification. It is likely that the econometrician overstates the conditional variance of returns from domestic assets, because the econometrician does not use all the information that investors use to calculate expected returns. On the other hand, if a great deal of the short-run uncertainty in exchange rates is pure noise, then the econometrician probably does not much overstate the variance of returns on foreign assets. The net effect of this is that the econometrician probably overstates the variance of portfolios that are biased toward home assets relative to internationally diversified portfolios.

Finally, the model does not address how the exchange rate is determined and who determines it. The exchange rate is pure noise, unrelated to fundamentals. But, a more complete story might include the behavior of the "chartists" of Frankel and Froot (1990). Their chartists are speculators whose expectations are not rational, but are determined by "charts" of past behavior of the nominal exchange rate. Since the actual level of the exchange rate is not important to the "fundamentalists" in our model, who have protected themselves from exchange rate noise by setting nominal prices ahead of time and hedging the effects of foreign exchange fluctuations on profits, a complete dynamic model might have a role for the chartists.

4 For example, see Tesar and Werner (1994) 
Appendix

Derivation of Share of Profits Hedged

Take the representative's indirect utility function to be a function of firms' total revenue, since ultimately the firm owner receives all of the revenue either as profit or wages. Let TR denote total revenue, so:

$\mathrm{TR}=\mathrm{z}+\mathrm{s}^{\prime} \mathrm{z}^{*}-\left(\mathrm{s}^{\prime}-\overline{\mathrm{s}}\right) \lambda \mathrm{z}^{*}$ where $\mathrm{z} \equiv \mathrm{pq}, \mathrm{z}^{*}=\mathrm{p}^{*} \mathrm{q}^{*}$, and $\lambda$ is the share of foreign revenues hedged.

First, note

$\mathrm{U}(\mathrm{TR}) \cong \mathrm{U}(\mathrm{E}(\mathrm{TR}))+\mathrm{U}^{\prime}(\mathrm{E}(\mathrm{TR}))(\mathrm{TR}-\mathrm{E}(\mathrm{TR}))+\frac{1}{2} \mathrm{U}^{\prime \prime}(\mathrm{E}(\mathrm{TR}))(\mathrm{TR}-\mathrm{E}(\mathrm{TR}))^{2}$.

Then,

$\mathrm{E}(\mathrm{U}(\mathrm{TR})) \cong \mathrm{U}(\mathrm{E}(\mathrm{TR}))+\frac{1}{2} \mathrm{U}^{\prime \prime}(\mathrm{E}(\mathrm{TR})) \operatorname{Var}(\mathrm{TR})$

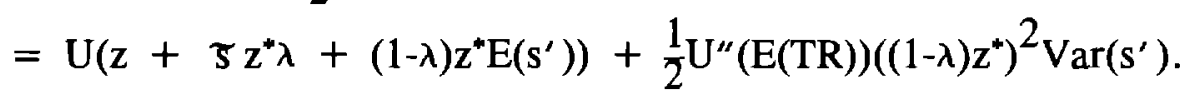

If $s^{\prime}$ is normally distributed, we have:

$\mathrm{E}\left(\mathrm{s}^{\prime}\right)=\mathrm{E}\left(\mathrm{e}^{\ln \left(\mathrm{s}^{\prime}\right)}\right)=\mathrm{e}^{\mathrm{E}\left(\ln \left(\mathrm{s}^{\prime}\right)\right)+(1 / 2) \operatorname{Var}\left(\ln \left(\mathrm{s}^{\prime}\right)\right)}$.

With $\mathrm{E}\left(\ln \left(\mathrm{s}^{\prime}\right)\right)=\ln (\mathrm{s})$, we have

$\mathrm{E}\left(\mathrm{s}^{\prime}\right)=s \mathrm{e}^{(1 / 2) \operatorname{Var}\left(\ln \left(\mathrm{s}^{\prime}\right)\right)} \cong \tau\left(1+\frac{1}{2} \operatorname{Var}\left(\ln \left(\mathrm{s}^{\prime}\right)\right)\right.$.

Also, $\operatorname{Var}\left(\mathbf{s}^{\prime}\right) \cong \mathbf{s}^{2} \operatorname{Var}\left(\ln \left(\mathbf{s}^{\prime}\right)\right)$.

The first-order condition, then, is $\frac{\mathrm{dE}(\mathrm{U}(\pi))}{\mathrm{d} \lambda} \cong$

$\mathrm{U}^{\prime}(\mathrm{E}(\mathrm{TR}))\left[-\frac{1}{2} \Im \mathrm{z}^{*} \operatorname{Var}\left(\ln \left(\mathrm{s}^{\prime}\right)\right)\right]-\mathrm{U}^{\prime \prime}(\mathrm{E}(\mathrm{TR})) \mathrm{z}^{* 2} \varsigma^{2} \operatorname{Var}\left(\ln \left(\mathrm{s}^{\prime}\right)\right)(1-\lambda)=0$, where we have assumed $\mathrm{U}^{\prime \prime \prime}(\mathrm{E}(\mathrm{TR})) \operatorname{Var}(\mathrm{TR}) \cong 0$.

From the first-order condition, we have $-\frac{1}{2}+\gamma \mathbf{R}(1-\lambda)=0$, where $R \equiv \frac{-\mathrm{E}(\mathrm{TR}) \mathrm{U}^{\prime \prime}(\mathrm{E}(\mathrm{TR}))}{\mathrm{U}^{\prime}(\mathrm{E}(\mathrm{TR}))}$ and $\gamma \equiv \frac{\mathrm{s} \mathrm{p}^{*} \mathrm{q}^{*}}{\mathrm{E}(\mathrm{TR})}$. 
This implies $\lambda=\frac{2 \mathrm{R}-(1 / \gamma)}{2 \mathrm{R}}$.

Since exchange rates are $\log$-normally distributed, and $E\left(\ln \left(s^{\prime}\right)\right)=\ln (\widetilde{s})$, the hedging problem of the foreign firms is symmetric. In our model $\gamma$ is approximately equal to $1 / 2$. 


\section{References}

Betts, Caroline, and Michael B. Devereux, 1996, Exchange rate dynamics in a model of pricing-to-market, University of British Columbia, working paper.

Chinn, Menzie D., and Richard A. Meese, 1995, Banking on currency forecasts: How predictable is change in money?, Journal of International Economics 38, 161-178.

Dornbusch, Rudiger, 1976, Expectations and exchange rate dynamics, Journal of Political Economy 84, 1161-1176.

Dombusch, Rudiger, 1987, Exchange rates and prices, American Economic Review 77, 93-106.

Engel, Charles, 1992, On the foreign exchange risk premium in a general equilibrium model, Journal of International Economics 32, 305-319.

Engel, Charles, 1993, Real exchange rates and relative prices: An empirical investigation, Journal of Monetary Economics 32, 35-50.

Engel, Charles, 1996, The forward discount anomaly and the risk premium: A survey of recent evidence, Joumal of Empirical Economics 3, 123-192.

Engel, Charles, and John H. Rogers, 1996, How wide is the border?, American Economic Review, forthcoming.

Flood, Robert P., and Andrew Rose, 1995, Fixing exchange rates: A virtual quest for fundamentals, Journal of Monetary Economics 36, 3-37.

Frankel, Jeffrey A., and Kenneth A. Froot, 1990, Chartists, fundamentalists, and the demand for dollars, in Anthony Courakis and Mark Taylor, eds., Private behavior and government policy in interdependent countries (Clarendon Press, Oxford).

Frankel, Jeffrey A., and Richard Meese, 1987, Are exchange rates excessively variable?, NBER Macroeconomics Annual 2, 117-162.

Friedman, Milton, 1953, The case for flexible exchange rates, in M. Friedman, Essays in positive economics (University of Chicago Press, Chicago).

Grilli, Vittorio and Nouriel Roubini, 1992, Liquidity and exchange rates, Journal of International Economics 32, 339-352.

Huang, Roger, 1981, The monetary approach to exchange rates in an efficient foreign exchange market: Tests based on volatility, Journal of Finance 36, 31-41.

Johnson, Harry G., 1972, The case for flexible exchange rates, in H.G. Johnson, Further essays in monetary economics (Allen and Unwin, London). 
King, Robert G.; Neil Wallace; and, Warren E. Weber, 1992, Nonfundamental uncertainty and exchange rates, Joumal of International Economics 32, 83-108.

Knetter, Michael, 1989, Price discrimination by U.S. and German exporters, American Economic Review 79, 198-210.

Knetter, Michael, 1993, International comparisons of pricing-to-market behavior, American Economic Review 83, 473-486.

Kroner, Kenneth F., and William D. Lastrapes, 1993, The impact of exchange rate volatility on international trade: Reduced form estimates using the GARCH-in-mean model, Journal of International Money and Finance 12, 298-318.

Krugman, Paul, 1987, Pricing to market when the exchange rate changes, in S. Arndt and J.D. Richardson, eds., Real-financial linkages among open economies (MIT Press, Cambridge, MA.).

Krugman, Paul, 1989, Exchange rate instakility (MIT Press, Cambridge).

MacDonald, Ronald, and Mark P. Taylor, 1994, The monetary model of the exchange rate: Long-run relationships, short-run dynamics and how to beat a random walk, Journal of International Money and Finance 13, 276-290.

Mankiw, N. Gregory, 1985, Small menu costs and large business cycles: A macroeconomic model of monopoly, Quarterly Journal of Economics 100, 529-539.

Manuelli, Rodolfo E. and James Peck, 1990, Exchange rate volatility in an equilibrium asset pricing model, International Economic Review 31, 559-574.

Mark, Nelson B., 1985, On time varying risk premia in the foreign exchange market: An econometric analysis, Joumal of Monetary Economics 16, 3-18.

Mark, Nelson B., 1995, Exchange rates and fundamentals: Evidence on long-horizon predictability, American Economic Review 85, 201-218.

Marston, Richard, 1990, Pricing to market in Japanese manufacturing, Journal of International Economics 29, 217-236.

Meese, Richard, 1986, Tests for bubbles in exchange markets: A case for sparkling rates?, Joumal of Political Economy 94, 345-373.

Meese, Richard, and Kenneth Rogoff, 1983a, Empirical exchange rate models of the seventies: Do they fit out of sample, Journal of International Economics 14, 3-24.

Meese, Richard, and Kenneth Rogoff, 1993b, The out-of-sample failure of exchange rate models: Sampling error or misspecification?, in J. Frenkel, ed., Exchange rates and international macroeconomics (University of Chicago Press, Chicago).

Rangan, Subramanian and Robert Z. Lawrence, 1993, The responses of U.S. firms to exchange rate fluctuations: Piercing the corporate veil, Brookings Papers on Economic Activity 2, 341-379. 
Tesar, Linda L. and Ingrid M. Werner, 1994, International equity transactions and U.S. portfolio choice, in Jeffrey A. Frankel, ed., The internationalization of equity markets (University of Chicago Press). 